\title{
PENATAAN DAN PEMBINAAN PEDAGANG KAKI LIMA DALAM PERSPEKTIF KOMUNIKASI PEMBANGUNAN DI SURAKARTA (Suatu Pendekatan Kuantitatif)
}

\author{
Muhamad Fajar Pramono \\ Institut Studi Islam Darussalam (ISID) Gontor, Ponorogo
}

\begin{abstract}
Always talking about controlling street vendors (PKL) like tangle and even there is always resistance. Such events occur in almost all regions in Indonesia. They differ in Surakarta voluntarily move to a location that has been prepared by the Government. The purpose of this study is expected to evaluate the response of vendors to process structuring and development of street vendors conducted by the City Government of Surakarta, especially during Joko Widodo-Rudy (20052012), so that it can be done peacefully. This study uses a quantitative approach using surveyexplanatory. To analyze the factors of interpersonal communication and democratic leadership style factors Surakarta City Government on the effectiveness of communication by using multiple regression analysis. Sample as many as 243 respondents using systematic random sampling. First results showed that the success of the process of structuring and development of street vendors in Surakarta in PKL assessment not only in the context of the process, but also in the sense of the results. Second, the results showed a factor of interpersonal communication and democratic leadership style factors jointly affect significantly on the effectiveness of Surakarta City Government communication in the process of structuring and development of street vendors. However, if both factors are seen individually that research shows that the democratic leadership style factors Surakarta City Government contributes more than a factor of interpersonal communication on the effectiveness of Surakarta City Government communication. Third, the results showed that the effectiveness of communication with Surakarta City Government Development productivity showed a positive relationship.
\end{abstract}

Keywords: Development Communication, Management and Development of street vendors and government Surakarta City 


\section{A. Pendahuluan}

Menurut Todaro dan Stilkind (1994) bahwa terdapat beberapa gejala yang dihadapi oleh negara berkembang, gejala tersebut adalah jumlah pengangguran yang besar dan semakin meningkat. Hal tersebut mengakibatkan kota-kota besar menghadapi berbagai macam problema sosial yang sangat pelik. Hal ini menjadi ciri umum kebanyakan perkotaan di negara-negara berkembang, termasuk Indonesia. Berdasarkan sensus penduduk 2010, jumlah penduduk Indonesia sudah mencapai 237,6 juta jiwa atau bertambah 32,5 juta jiwa sejak tahun 2000 . Artinya, setiap tahun selama periode 2000-2010, jumlah penduduk bertambah 3,25 juta jiwa.

Kehadiran Pedagang Kaki Lima (PKL) di kota-kota besar merupakan bagian yang tidak dapat dipisahkan dari perkembangan kota. Berdasarkan data Asosiasi Pedagang Kaki Lima Indonesia (APKLI) menyebutkan, jumlah PKL yang ada di Indonesia sebanyak 22,9 juta orang. Padahal saat ini jumlah pengusaha mikro yang ada dan tersebar di seluruh wilayah di Indonesia mencapai 53,1 juta orang. Ini artinya, hampir 50 persen pengusaha mikro di negeri ini merupakan pengusaha yang bergerak di sektor PKL.

Usaha kecil seperti Pedagang Kaki Lima (PKL) merupakan aset ekonomi bangsa Indonesia, yang memberi andil besar dalam hal ketenaga-kerjaan, pengentasan kemiskinan dan menjadi katup pengaman ekonomi kerakyatan. Pada tahun 1997-1998 sewaktu terjadi krisis ekonomi yang melanda negara kita, banyak perusahaan besar mengalami gulung tikar dan merumahkan karyawannya, akan tetapi sektor informal seperti PKL tidak begitu terkena imbasnya, malah mereka bisa menolong pekerja yang di PHK, masyarakat kecil yang sulit mendapatkan pekerjaan dan lulusan perguruan tinggi yang kurang beruntung.

Namun, dibalik peranan dan fungsinya yang menopang perekonomian rakyat bawah tersebut, kehadiran sektor informal PKL di kota-kota besar diidentifikasikan telah memunculkan berbagai permasalahan. Oleh sebab itu, sudah sewajarnya bila permasalahan yang ditimbulkan oleh PKL ditangani bersama dengan cara melakukan penertiban tanpa "membunuh" sektor informal itu sendiri. Sebagai wujud komitmen pemerintah Republik Indonesia terhadap PKL sebenarnya sudah lama memperhatikan persoalan ini. Dalam perspektif Bung Hatta (Wakil Presiden RI Pertama), pemerintah sebenarnya aktor yang tak henti mengkreasikan tumbuhnya kelembagaan ekonomi serta merestorasi kelembagaan ekonomi untuk tujuan aktualisasi peran dan aspirasi ekonomi kaum periferal (Anwari, 2012).

Jadi, dengan adanya berbagai produk hukum, baik dalam bentuk peraturan menteri maupun peraturan daerah (perda), hal ini menunjukkan bahwa Pedagang Kaki lima (PKL) telah lama menjadi perhatian serius pemerintah pusat maupun daerah, termasuk Kota Surakarta. Bisa disebut sebagai amanat konstitusi atau undang-undang. Persoalannya tidak tidak semata-mata dalam tataran kebijakan, tetapi terkait dengan implementasinya. Implementasinya tergantung gaya kepemimpinan dan pola komunikasi pimpinan daerah, termasuk kondisi subyektif dan kondisi obyektif masing-masing daerah, termasuk Kota Surakarta.

Berbicara soal Pedagang Kaki Lima (PKL) dan penertiban dalam tataran implementasinya bagaikan benang kusut yang tak ada ujungnya, selalu saja ada perlawanan, selalu saja ricuh, 
bentrok, selalu saja ada kekerasan dan tangis pilu Pedang Kaki Lima (PKL) yang digusur dari tempat usaha mereka mengais sesuap nasi. Dan peristiwa semacam ini terjadi dihampir seluruh daerah di Indonesia, mereka para pedagang kaki Lima (PKL) harus tergusur dengan paksa karena dipaksa. Lain halnya PKL (Pedagang kaki Lima) yang terdapat di Surakarta mereka dengan sukarela berpindah tempat berdagang ke lokasi yang telah disiapkan oleh Pemerintah dengan menaiki angkutan yang telah disiapkan Pemerintah Kota dengan arak-arakan yang panjang, meriah mereka dengan sukacita menuju lokasi yang baru. Program penataan dan pembinaan PKL di Surakarta dalam bentuk relokasi PKL dari Monumen Banjarsari ke Pasar Klitikan Notoharjo Semanggi, yang banyak mendapat ekspose publik karena berhasil dilakukan tanpa kekerasan, sesungguhnya tidaklah berlangsung mudah.

Berdasarkan latar belakang di atas, penelitian ini mencoba untuk mengeksplorasi dan menganalisis fenomena keberhasilan penataan dan pembinaan Pedagang Kaki Lima (PKL) di Surakarta. Sedangkan rinciannya, penelitian ini akan melihat lebih mendalam:

1. Bagaimanakah respons Pedagang Kaki Lima (PKL) terhadap proses penataan dan pembinaan Pedagang Kaki Lima (PKL) di Surakarta tersebut, terutama terkait dengan efektivitas komunikasi yang dilakukan oleh Pemkot Surakarta?

2. Apakah faktor komunikasi interpersonal dan faktor gaya kepemimpinan demokratis Pemkot Surakarta mempunyai pengaruh yang nyata terhadap efektivitas komunikasi dalam konteks penataan dan pembinaan PKL di Surakarta ? Diantara faktor-faktor tersebut mana yang paling dominan?

3. Dan adakah korelasi antara efektivitas komunikasi Pemkot Surakarta dengan produktivitas pembangunan di Kota Surakarta?

Sesuai dengan rumusan masalah di atas, maka tujuan yang diharapkan dari penelitian ini adalah sebagai berikut:

Ingin mengetahui respons Pedagang Kaki Lima (PKL) terhadap proses penataan dan pembinaan Pedagang Kaki Lima (PKL) di Surakarta tersebut, terutama terkait dengan efektivitas komunikasi yang dilakukan oleh Pemkot Surakarta dalam konteks penataan dan pembinaan PKL di Surakarta.

Menganalisis pengaruh faktor komunikasi interpersonal dan faktor gaya kepemimpinan demokratis Pemkot Surakarta terhadap efektivitas komunikasi tersebut dan ingin menganalisis faktor yang paling dominan dari faktor-faktor tersebut.

Menganalisa korelasi antara faktor fektivitas komunikasi dan faktor produktivitas pembangunan di Surakarta.

Berdasarkan dari tujuan penelitian di atas, yang diharapan kegunaan dari penelitian ini:

Bagi pengembangan dunia keilmuan, khususnya Studi Penyuluhan dan Komunikasi Pembangunan di Indonesia adalah ingin mengetahui lebih jauh aspek-aspek lain dari teori komunikasi pembangunan, terutamata dalam teori komunikasi interpersonal dan teori gaya kepemimpinan demoratis dalam kasus pembinaan dan penataan Pedagang Kaki Lima (PKL) di 
Surakarta.

Bagi pemerintahan daerah (Kota/ Kabupaten) di Indonesia, yang diharapkan dari hasil penelitian ini bisa sebagai model atau inspirasi komunikasi pembangunan dalam berbagai bidang, terutama dalam penataan dan pembinaan Pedagang Kaki Lima (PKL). Sedangkan khusus untuk Pemerintahan Kota Surakarta sebagai input atau bahan evaluasi untuk lebih menyempurnakan program penataan dan pembinaan PKL ke depan.

\section{B. Review Pustaka}

Di penghujung tahun 60 -an, ilmu komunikasi mencatat perkembangan menarik ketika kalangan jurnalis menerapan teori dan konsep komunikasi untuk keperluan penyelenggaraan program pembangunan. Mereka menyebutnya Jurnalisme Pembangunan. Cikal-bakal lain yang mendorong tumbuhnya metodologi ini di wilayah Asia Tenggara adalah ketika mulai dikembangkannya mata studi Komunikasi Pertanian di University of Philippine, Los Banos. Belakangan, istilah-istilah untuk menyebut program ini pun mulai beragam seperti, Komunikasi Penunjang Pembangunan (Development Support Communication), Pengiklanan Pembangunan (Development Advertising) dan sebagainya.

Peranan komunikasi pembangunan telah banyak dibicarakan oleh para ahli, pada umumnya mereka sepakat bahwa komunikasi mempunyai andil penting dalam pembangunan. Everett M. Rogers (1985) menyatakan bahwa, secara sederhana pembangunan adalah perubahan yang berguna menuju suatu sistem sosial dan ekonomi yang diputuskan sebagai kehendak dari suatu bangsa. Pada bagian lain Rogers menyatakan bahwa komunikasi merupakan dasar dari perubahan sosial.

John Naisbitt dalam bukunya Megatrends (1998) menyatakan ada sembilan kecendrungan besar yang sekarang sedang berlangsung di dunia. Salah satu kecenderungan besar itu adalah beralihnya masyarakat industri ke masyarakat informasi. Dalam masyarakat industri, produksi dihasilkan oleh interaksi manusia dengan alam yang terolah, sedangkan masyarakat informasi produksi merupakan hasil interaksi antara manusia dengan manusia. Jobn Naisbitt menyebutkan pula lima hal yang diperhatikan mengenai perubahan masyarakat industri ke masyarakat informasi. Pertama, masyarakat informasi merupakan suatu realitas ekonomi. Kedua, inovasi di bidang komunikasi dan teknologi komputer akan menambah langkah perubahan dalam penyebaran informasi dan percepatan arus informasi. Ketiga, teknologi informasi yang baru diterapkan dalam tugas industri yang lama, secara perlahan akan melahirkan kreativitas dan proses produksi yang baru. Keempat, dalam masyarakat informasi, individu yang menginginkan kemampuan menulis dan kemampuan dasar membaca lebih bagus dari masa lalu. Kelima, keberhasilan dan kegagalan teknologi komunikasi ditentukan oleh prinsip teknologi tinggi dan sentuhan yang tinggi pula.

Di Indonesia, minimal sampai akhir 1970-an, komunikasi pembangunan masih menggabungkan pendekatan media massa dan komunikasi interpersonal. Teoriyang mendasarinya ialah komunikasi dua langkah (Hilbrink, 1976). Pada masa itu radio menempati posisi penting. 
Isi siaran disesuaikan dengan kebutuhan pembangunan. Sementara pada masyarakat tani dikembangkan kelompok media. Pada dekade 1980-an muncul pemahaman baru tentang kesalahan konseptualisasi teoretis (Melkote, 1991). Pemahaman ini masih dipengaruhi oleh pemikiran satu dekade sebelumnya. Semula dipandang bahwa komunikasi dapat menyelesaikan permasalahan pembangunan tanpa melakukan hal lain. Pada saat ini muncul kesadaran bahwa ada masalah pembangunan yang memiliki kaitan sangat rendah dengan komunikasi, bahkan komunikasi meningkatkan kesenjangan sosial dan ekonomi masyarakat.

Rogers (1989) mengatakan komunikasi tetap dianggap sebagai perpanjangan tangan para perencana pemerintah, dan fungsi utamanya adalah untuk mendapatkan dukungan masyarakat dan partisipasi mereka dalam pelaksanaan rencana-rencana pembangunan. Dari pendapat Rogers ini jelas bahwa komunikasi memegang peranan penting setiap pembangunan dalam suatu bangsa. Dan karenanya pemerintah dalam melancarkan komunikasinya perlu memperhatikan strategi apa yang dapat digunakan untuk menyampaikan pesan sehingga efek yang diharapkan itu sesuai dengan harapan.

\section{Teori Komunikasi Interpersonal}

Dalam penyelenggaraan pembangunan, diperlukan suatu sistem komunikasi agar terjalin komunikasi efektif dan memiliki makna yang mampu mengarahkan pencapaian tujuan pembangunan. Hal itu perlu sekali dilakukan karena proses pembangunan melibatkan berbagai elemen masyarakat. Komunikasi pembangunan ini harus mengedepankan sikap aspiratif, konsultatif dan relationship. Karena pembangunan tidak akan berjalan dengan optimal tanpa adanya hubungan sinergis antara pelaku dan obyek pembangunan. Apalagi proses pembangunan ke depan cenderung akan semakin mengurangi peran pemerintah, seiring semakin besarnya peran masyarakat.

Denis Mc Quail (1993) berpendapat bahwa secara umum proses komunikasi dalam masyarakat dapat berlangsung dalam 6 tingkatan yaitu: intra personal, interpersonal, komunikasi kelompok, komunikasi organisasi dan komunikasi massa. Komunikasi interpersonal ialah komunikasi yang dilakukan kepada pihak lain untuk mendapatkan umpan balik, baik secara langsung (face to face) maupun dengan media. Berdasarkan definisi ini maka terdapat kelompok maya atau faktual (Burgon \& Huffner, 2002). Contoh kelompok maya, misalnya komunikasi melalui internet (chatting, face book, email, etc.). Berkembangnya kelompok maya ini karena konsekuensi dari perkembangan teknologi media komunikasi.

Menurut Effendi (2001), pada hakekatnya komunikasi interpersonal adalah komunikasi antar komunikator dengan komunikan, komunikasi jenis ini dianggap paling efektif dalam upaya mengubah sikap, pendapat atau perilaku seseorang, karena sifatnya yang dialogis berupa percakapan. Arus balik bersifat langsung, komunikator mengetahui tanggapan komunikan ketika itu juga. Pada saat komunikasi dilancarkan, komunikator mengetahui secara pasti apakah komunikasinya positif atau negatif, berhasil atau tidaknya. Jika ia dapat memberikan kesempatan pada komunikan untuk bertanya seluas-luasnya. 
Rogers dan Shoemaker (1971) mengatakan bahwa saluran interpersonal masih memegang peranan penting dibanding dengan media massa, terlebih-lebih di negara-negara yang belum maju di mana kurang tersedianya media massa yang dapat menjangkau khalayak terutama warga pedesaan, tingginya tingkat buta huruf dan tidak sesuainya pesan-pesan yang disampaikan dengan kebutuhan masyarakat. Lazarsfeld (Susanto, 1988) mengatakan bahwa media massa hanya merupakan 1) peliput ganda pesan dan penyebar ide secara mendatar dan 2) penguat artinya hanya didengar apabila sependapat dengan pendapat komunikan. Jadi saluran interpersonal dipergunakan apabila kita mengharapkan efek perubahan tingkah laku (behavior change) dari komunikan.

Fiske dan Hartley (1980) menunjukkan faktor-faktor umum yang mempengaruhi efektivitas suatu komunikasi :

1. Semakin besar monopoli sumber komunikasi terhadap penerima, semakin besar kemungkinan penerima akan menerima pengaruh atau pesan tersebut.

2. Pengaruh komunikasi yang paling besar adalah pada saat pesan yang disampaikan sesuai dengan pendapat, kepercayaan dan watak penerima.

3. Komunikasi dapat menyebabkan perubahan yang efektif atas masalah yang tidak dikenal, dianggap ringan, dan bukan inti, yang tidak terletak pada pusat sistem nilai penerima itu.

4. Komunikasi akan lebih efektif jika sumber dipercaya memiliki keahlian, status yang tinggi, obyektif, atau disukai, tetapi yang paling utama adalah sumber memiliki kekuasaan dan dapat diidentifikasikan.

5. Konteks sosial, kelompok atau kelompok referensi akan menjadi penengah dalam komunikasi dan mempengaruhi apakah komunikasi akan diterima ataukah ditolak.

Ringkasnya, komunikasi interpersonal adalah proses mempengaruhi pendapat, sikap dan tindakan dengan menggunakan manipulasi psikologis sehingga orang tersebut bertindak seperti atas kehendaknya sendiri. Dalam berbagai situasi kita berusaha mempengaruhi sikap orang lain, dan berusaha agar orang lain memahami ucapan kita. Dalam terminologi komunikasi kemudian dikenal dengan komunikasi persuatif.

Dalam penelitian ini untuk mengukur efektivitas komunikasi interpersonal mengacu pendapatnya Cruden dan Sherman (2005). Ada beberapa faktor yang mempengaruhi:

\section{Completeness (Lengkap)}

Suatu pesan atau informasi dapat dikatakan lengkap, bila berisi semua materi yang diperlukan agar penerima pesan dapat memberikan tanggapan yang sesuai dengan harapan pengirim pesan.

\section{Conciseness (Singkat)}

Suatu pesan dikatakan concise bila dapat mengutarakan gagasannya dalam jumlah kata sekecil mungkin (singkat, padat tetapi jelas) tanpa mengurangi makna, namun tetap menonjolkan gagasannya. 


\section{Consideration (Meyakinkan)}

Penyampaian pesan, hendaknya menerapkan empati dengan mempertimbangkan dan mengutamakan penerima pesan.

\section{Concreteness (kongkrit)}

Penyampaian pesan hendaknya disampaikan dengan bahasa yang gambalang, pasti dan jelas.

\section{Clarity (Kejelasan)}

Pesan hendaknya disampaikan dengan bahasa yang mudah dimengerti dan mudah diinterpretasikan serta memiliki makna yang jelas.

\section{Courtessy (Kesopanan)}

Pesan disampaikan dengan gaya bahasa dan nada yang sopan, akan memupuk hubungan baik dalam komunikasi bisnis.

\section{Correctness (ketelitian)}

Pesan hendaknya dibuat dengan teliti, dan menggunakan tata bahasa, tanda baca dan ejaan dengan benar (formal atau resmi).

\section{Teori Gaya Kepemimpinan Demokratis}

Konsep komunikasi pembangunan sangat membuka peluang untuk mendorong komunikasi intensif melalui dialog dengan kelompok-kelompok strategis dalam rangka membangun kemitraan untuk mempengaruhi kebijakan publik sebelum diputuskan. Berbagai kelompok yang perlu dilibatkan dalam kemitraan antara lain Perguruan Tinggi, LSM, pers dan berbagai elemen pendukung pembangunan lainnya. Agar komunikasi pembangunan berjalan dengan efektif, maka diperlukan suatu pusat komunikasi yang menjadi rujukan dari pelaku-pelaku pembangunan maupun pihak-pihak yang berkompeten dalam penyelenggaraan pembangunan untuk memperoleh informasi dan koordinasi pembangunan secara terpadu.

Suatu hal yang penting dicatat Model Lasswell (1948) bahwa proses komunikasi dipengaruhi oleh beberapa faktor, yaitu: komunikator, pesan, medium, komunikan dan efek. Rogers (1983) mengatakan kredibilitas adalah tingkat di mana komunikator dipersepsi sebagai suatu kepercayaan dan kemampuan oleh penerima. Hovland (Rogers, 1983) dalam penelitiannya mengatakan bahwa pesan yang disampaikan oleh komunikator yang tingkat kredibilitasnya tinggi akan lebih banyak memberi pengaruh kepada perubahan sikap dalam penerimaan pesan daripada jika disampaikan oleh komunikator yang tingkat kredibilitasnya rendah. Juga sebagaimana pendapat Rakhmat (1989) mengatakan dalam berkomunikasi yang berpengaruh terhadap komunikan bukan hanya apa yang disampaikan, tetapi juga keadaan komunikator secara keseluruhan.

Jadi ketika suatu pesan disampaikan, komunikan tidak hanya_mendengarkan apa yang dikatakan tetapi ia juga memperhatikan siapa yang mengatakan. Selanjutnya Tan (1971) 
mengatakan kredibilitas sumber terdiri dari dua unsur, yaitu keahlian dan kepercayaan. Keahlian diukur dengan sejauhmana komunikan menganggap komunikator mengetahui jawaban yang benar, sedangkan kepercayaan dioperasionalisasikan sebagai persepsi komunikan tentang sejauhmana komunikator bersikap tidak memihak dalam penyampaian pesan.

Menurut Courtois (1989) bahwa "kelompok tanpa pimpinan seperti tubuh tanpa kepala, mudah menjadi sesat, panik, kacau, anarki. Dalam beberapa pengertian organisasi ditegaskan adanya kepemimpinan sebagai salah satu faktor organisasi. Dari bukti-bukti tersebut nampak dengan tegas bahwa kepemimpinan merupakan masalah sentral dalam kepengurusan organisasi. Maju mundurnya organisasi, dinamis statisnya organisasi, tumbuh kembangnya organisasi, mati hidupnya organisasi, senang tidaknya seseorang bekerja dalam suatu organisasi, serta tercapai tidaknya tujuan organisasi, sebagian ditentukan oleh tepat tidaknya kepemimpinan yang diterapkan dalam organisasi yang bersangkutan.

Kata kepemimpinan terjemahan dari bahasa Inggris, yaitu leadership. Kepemimpinan adalah pengaruh antar pribadi, dalam situasi tertentu dan langsung melalui proses komunikasi untuk mencapai satu atau beberapa tujuan tertentu. Kepemimpinan adalah sikap pribadi, yang memimpin pelaksanaan aktivitas untuk mencapai tujuan yang diinginkan. Pengertian lain, yaitu: aktivitas mempengaruhi kemampuan mengajak, kemampuan mengarahka, kemampuan menciptakan, proses mempengaruhi, usaha mengarahkan, menggunakan wewenang dan membuat orang bertindak, awal dari tindakan, kemampuan membuat orang bertindak, hubungan kekuasaan, saling pengaruh antar pribadi, hubungan dan pemeliharaan struktur, seni mengkoordinasi dan memotivasi, aktivitas yang memudahkan kelompok dan sebagainya (Sutarto, 1989).

Sebagai suatu fenomena, kepemimpinan dalam organisasi telah secara ekstensif dipelajari selama beberapa tahun lamanya. Secara historis, terdapat dua pendekatan utama dalam studi kepemimpinan, yaitu leadership traits dan leadership behaviours sebagai pusat perhatian. Selama beberapa dekade awal abad ini, ratusan studi telah dilakukan untuk mengidentifikasi makna penting karakter kepemimpinan (leadership traits). Pendekatan ini berupaya menganalisis karakter personal, psikologis dan fisik dari strong leaders. Asumsi yang mendasari pendekatan ini adalah bahwa beberapa karakter dasar atau seperangkat karakter dapat membedakan antara pemimpin dan non-pemimpin (Robbins, 2001).

Kegagalan leadership traits untuk menjelaskan kepemimpinan, beberapa peneliti manajemen kemudian memulai meneliti variabel lainya yaitu perilaku atau tindakan pemimpin. Hipotesis baru dimunculkan yaitu bahwa perilaku pemimpin yang efektif berbeda dengan perilaku pemimpin yang tidak efektif. Dalam kajian tentang leadership behaviours ini terdapat dua macam studi, yaitu The Michigan Studies dan The Ohio States Studies (Thoha, 2001).

Baik teori kepemimpinan dari Michigan maupun Ohio State memiliki peran yang sangat penting dalam pengembangan pemikiran kontemporer tentang kepemimpinan. Mereka mengasumsikan bahwa perilaku merupakan variabel independen. Asumsi ini mengartikan bahwa seorang pemimpin dapat menunjukkan perbedaan tingkat initiating-structure dan consideration 
pada saat yang sama. Dan lebih khusus lagi berkaitan dengan konsentrasi yang tidak berpusat pada apa itu pemimpin, sebagaimana menjadi pusat perhatian dari traits approach. Namun mengkonsentrasikan diri pada apa yang dilakukan pemimpin (perilaku) (Robbins, 2001).

Selama perang dunia II studi mengenai teori kepemimpinan mengalami perubahan arah yang signifikan dari mempelajari ciri-ciri individu menjadi pola perilaku pemimpin yang disebut dengan leadership styles. Dengan demikian maka fokus beralih dari "siapa pemimpin itu" menjadi "bagaimana seorang pemimpin berperilaku atau menjalankan gaya kepemimpinan" Para sarjana membagi tipe kepemimpinan menjadi delapan (8):1) Tipe kharismatik. 2) Tipe paternalistic. 3) Tipe militeristis. 4) Tipe otokratis 5) Tipe Lousser Faire. 6) Tipe Populistis. 7) Tipe Administratif. 8) Tipe demokratis.

Sedangkan menurutLewin (Robbins, 2001), dari UniversityofIowaStudies menyimpulkan ada tiga gaya kepemimpinan, yaitu: Gaya kepemimpinan otoriter (authoritarian leadership style), gaya kepemimpinan demokratis (democratic leadership style) dan gaya kepemimpinan laissez-faire (laissez-faire leadership style). Menurut Rivai (2003) gaya kepemimpinan otoriter (authoritarian leadership style) adalah gaya kepemimpinan yang menggunakan metode pendekatan kekuasaan dalam mencapai keputusan dan pengembangan strukturnya, sehingga kekuasaanlah yang paling diuntungkan dalam organisasi. Robbins dan Coulter (2004) menyatakan gaya kepemimpinan otoriter mendeskripsikan pemimpin yang cenderung memusatkan kekuasaan kepada dirinya sendiri, mendikte bagaimana tugas harus diselesaikan, membuat keputusan secara sepihak, dan meminimalisasi partisipasi karyawan.

Sedangkan gaya kepemimpinan demokratis (democratic leadership style), menurut Robbins dan Coulter (2004) bahwa gaya kepemimpinan demokratis mendeskripsikan pemimpin yang cenderung mengikut-sertakan karyawan dalam pengambilan keputusan, mendelegasikan kekuasaan, mendorong partisipasi karyawan dalam menentukan bagaimana metode kerja dan tujuan yang ingin dicapai, dan memandang umpan balik sebagai suatu kesempatan untuk melatih karyawan.

Sebagai pembanding perlu dikemukakan di sini adalah kepemimpinan transformatif. Kepemimpinan transformatif merupakan pendekatan untuk mendobrak. Dobrak gaya kepemimpinan tradisional. Dobrak pola pikir lama yang memandang bahwa hubungan antara pemimpin dan karyawan (leadership and followership) semata berlandaskan reward yang diberikan. Gagasan awal mengenai gaya kepemimpinan transformasional dan transaksional ini dikembangkan oleh James MacFregor Gurns yang menerapkannya dalam konteks politik. Gagasan ini selanjutnya disempurnakan serta diperkenalkan ke dalam konteks organisasional oleh Bernard Bass (Berry dan Houston, 1993).

Sejauhmana pemimpin dikatakan sebagai pemimpin transformasional, Bass (1990) dan Koh, dkk. (1995) mengemukakan bahwa hal tersebut dapat diukur dalam hubungan dengan pengaruh pemimpin tersebut berhadapan karyawan. Oleh karena itu, Bass (1990) mengemukakan ada tiga cara seorang pemimpin transformasional memotivasi karyawannya, yaitu dengan: 1) mendorong karyawan untuk lebih menyadari arti penting hasil usaha; 2) mendorong karyawan 
untuk mendahulukan kepentingan kelompok; dan 3) meningkatkan kebutuhan karyawan yang lebih tinggi seperti harga diri dan aktualisasi diri.

Dalam konteks penelitian ini untuk melihat gaya kepemimpinan Pemkot Surakarta dengan menggunakan perspektif gaya kepemimpinan demokratis (democratic leadership style), dengan melihat bagaimana Pemkot Surakarta mengikut-sertakan karyawan dalam pengambilan keputusan, mendelegasikan kekuasaan, mendorong partisipasi karyawan dalam menentukan bagaimana metode kerja dan tujuan yang ingin dicapai, dan memandang umpan balik sebagai suatu kesempatan untuk melatih karyawan.

Secara sederhana atas dasar berbagai teori di atas dirumuskan kerangka teoritik sebagai berikut. Keberhasilan program penataan dan pembinaan Pedagang Kaki Lima (PKL) diukur dengan dua pendekatan, yaitu pendekatan proses (process approach) dan pedekatan hasilnya (result approach). Pendekatan proses (process approach) bisa dilihat sejauhmana efektivitas komunikasi dengan indikator tingkat pemahaman, dukungan PKL dan keterlibatan PKL terhadap program tersebut. Sehingga proses penataan dan pembinaan PKL dalam bentuk relokasi PKL Monumen Banjarsari ke Pasar Klitikan Notoharjo bisa dilakukan secara damai. Sedangkan pendekatan hasil (result approach) bahwa program bisa dilihat dari segi produktivitas pembangunan, yaitu apakah program tersebut berpengaruh terhadap peningkatan pendapatan daerah atau terhadap pendapatan PKL-nya sendiri, terwujudnya keamanan dan kenyamanan kerja serta ketertiban dan kebersihan kota.

Adapun faktor-faktor yang mempengaruhi keberhasilan program penataan dan pembinaan PKL dalam bentuk relokasi PKL Monumen Banjarsari ke Pasar Klitikan Notoharjo, Semanggi sangat ditentukan oleh kualitas komunikasi pembangunan Pemkot Surakarta, yang bisa dilihat: Pertama, dari faktor komunikasi interpersonal Pemkot Surakarta, yang terdiri dari indikator kemampuan menyampaikan pesan secara lengkap, faktor menyampaikan pesan secara singkat, kemampuan menyampaikan pesan yang meyakinkan, kemampuan menyampaikan pesan dengan jelas, kemampuan menyampaikan pesan dengan sopan dan kemampuan menyampaikan pesan dengan teliti secara. Kedua, bisa dilihat dari faktor gaya kepemimpinan demokratis Pemkot Surakarta, yang terdiri dari indikator adanya pembagian kekuasaan dengan pihak lain, faktor adanya kepercayaan terhadap bawahan, faktor pengambilan kebijakan yang memperhatikan kedua belah pihak dan faktor keterlibatan bawahan. Secara sederhana bisa dilihat pada gambar 1 : 


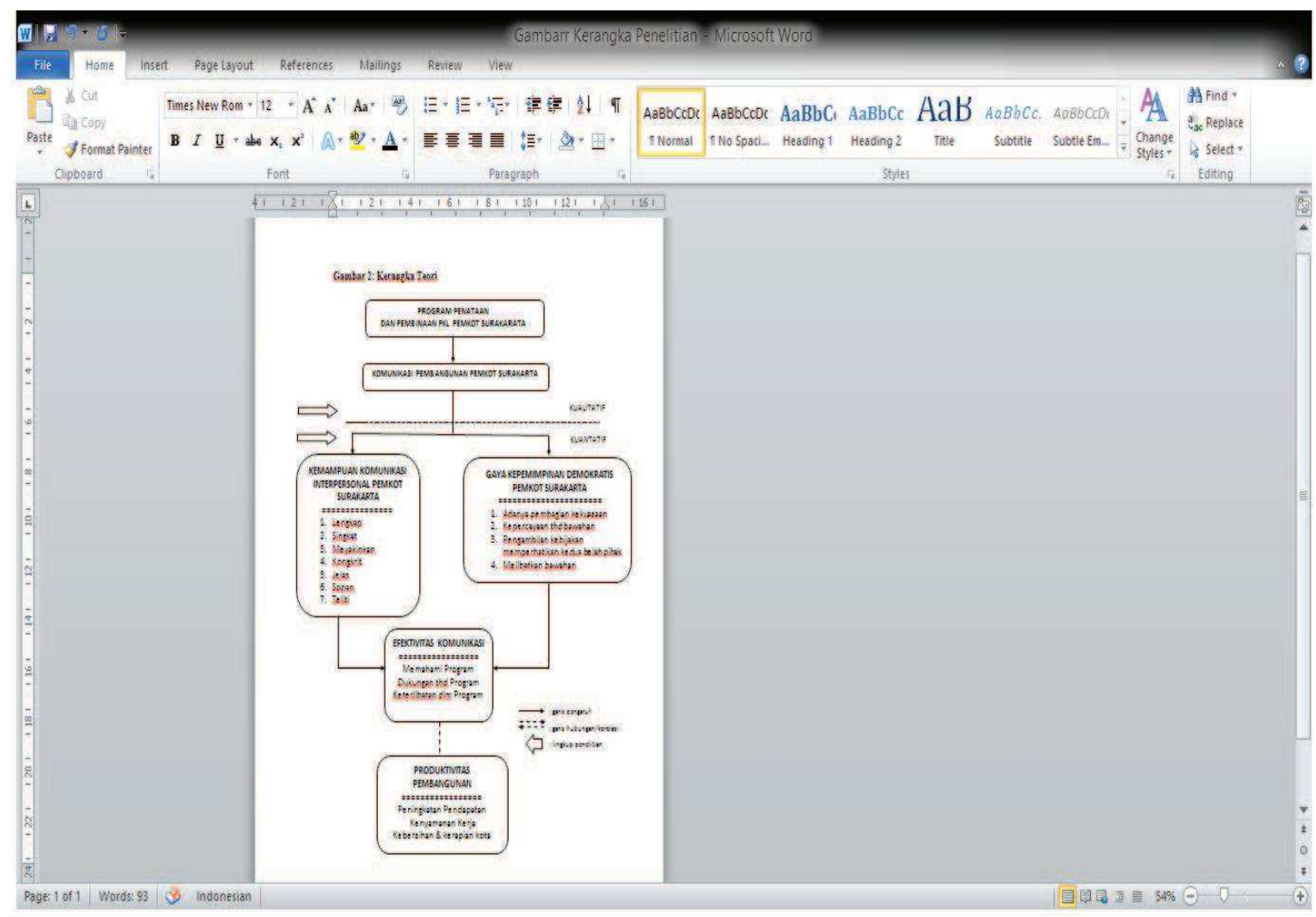

Gambar 1: Kerangka Penelitian

Berdasarkan rumusan masalah dan kajian teroristis serta kerangka teori yang telah dikemukakan sebelumnya, maka dapat diajukan hipotesis untuk menganalisis penilaian PKL terhadap proses penataan dan pembinaan PKL di Surakarta sebagai berikut:

1. Diduga bahwa faktor komunikasi interpersonal dan faktor gaya kepemimpinan demokratis Pemkot Surakarta mempunyai pengaruh yang nyata terhadap efektivitas komunikasi.

2. Dan diantara faktor-faktor tersebut yang diduga paling dominan adalah faktor komunikasi interpersonal Pemkot Surakarta.

3. Diduga bahwa ada korelasi positif antara efektivitas komunikasi Pemkot Surakarta dengan produktivitas pembangunan di Surakarta.

\section{E. Metodologi}

Metode penelitian ini menggunakan pendekatan mix-method, yaitu perpaduan atau percampuran antara penelitian kualitatif dan kuantitatif (Usman dan Akbar, 1995, Nazir, 1999; Singarimbun \& Effendi, 1989). penelitian ini menggunakan survei-eksplanasi (explanatory atau confirmatory, yakni untuk menjelaskan hubungan kausal dan pengujian hipotesis (Singarimbun, 1989). Untuk menganalisis faktor komunikasi interpersonal dan faktor gaya kepemimpinan demokratis Pemkot Surakarta terhadap efektivitas komunikasi dengan menggunakan analisis regresi ganda (multiple regression analysis) (Usman dan Akbar, 1995). Sedangkan untuk 
menganalisis hubungan antara efektivitas komunikasi (memahami, mendukung dan terlibat) dengan produktifitas pembangunan (peningkatan pendapatan, kenyamanan kerja, dan kebersihan serta kerapian kota Surakarta) dengan uji korelasi.

Penelitian ini dengan mengambil lokasi penelitian di Pasar Klitikan, Notoharjo, Semanggi, Kecamatan Pasar Kliwon, Surakarta. Alasan pemilihan lokasi yang terakhir ini karena daerah tersebut sebagai lokasi program penataan dan pembinaan (relokasi) Pedagang Kaki Lima (PKL) Pemerintahan Kota Surakarta, yang umumnya berasal dari Monumen Banjarsari. Sampel untuk mengetahui penilaian terhadap proses penataan dan pembinaan PKL dalam penelitian ini sebanyak $243 \mathrm{PKL}$ dari jumlah total populasi $970 \mathrm{PKL}$. Sedangkan untuk penentuan respondennya dengan menggunakan teknik pengambilan acak sistematis (systematic random sampling) (Nazir, 1999; Singarimbun \& Effendi, 1989), yaitu suatu metode pengambilan sampel, dimana hanya unsur pertama saja dari sampel dipilih secara acak, sedangkan unsurunsur selanjutnya dipilih secara sistematis menurut suatu pola tertentu.

\section{F. Hasil dan Pembahasan}

Hasil penelitian menunjukkan, Pertama, bahwa keberhasilan proses penataan dan pembinaan PKL di Surakarta dalam penilaian PKL tidak hanya dalam konteks proses, yaitu bagaimana tingkat efektvitas komunikasi Pemkot Surakarta, tetapi juga dalam arti hasilnya atau dampaknya, yaitu terlihat dalam produktivitas pembangunan Pemkot Surakarta dalam konteks pembinaan dan penataan PKL, sekalipun dalam katagori sedang.

Kedua, hasil penelitian menunjukkan faktor komunikasi interpersonal dan faktor gaya kepemimpinan demokratis secara bersama-sama berpengaruh secara nyata (signifikan) terhadap efektivitas komunikasi Pemkot Surakarta dalam proses penataan dan pembinaan PKL. Namun jika kedua faktor tersebut dilihat secara sendiri-sendiri bahwa penelitian menunjukkan bahwa faktor gaya kepemimpinan demokratis Pemkot Surakarta memberi kontribusi lebih besar daripada faktor komunikasi interpersonal terhadap efektivitas komunikasi Pemkot Surakarta. Lebih jelasnya lihat tabel 1 .

Tabel 1: Hasil Analisis Faktor-Faktor Yang Mempengaruhi Efektivitas

Komunikasi Pemkot Surakarta dalam Penataan dan Pembinaan

\begin{tabular}{llccc}
\hline No & \multicolumn{1}{c}{ Variabel } & $\begin{array}{c}\text { Koefisien } \\
\text { Regresi }\end{array}$ & t-hitung & Sig \\
\hline \multirow{2}{*}{$\begin{array}{l}\text { konstanta } \\
2\end{array}$} & Komunikasi Interpersonal (X1) & 16,925 & 3,557 &, 000 \\
& Kepemimpinan Demokratis (X2) &,- 102 & $-0,656$ &, 513 \\
& Keterangan: & 1,174 & 5,954 &, 000 \\
& N & & & \\
& R & 243 & & \\
& R Square & 0,849 & & \\
& & 0,720 & &
\end{tabular}




\begin{tabular}{llccc}
\hline No & Variabel & Koefisien & t-hitung & Sig \\
\hline Adjusted R Square & Regresi & ( & \\
F-hitung & 308,846 & & \\
F-tabel $a=0,05$ & 1,970 & \\
sig & 0,000 & \\
\hline
\end{tabular}

Sumber: Data Primer, 2014 diolah dengan SPSS 15

Ketiga, hasil penelitian menujukkan bahwa efektivitas komunikasi dengan produktivitas Pembangunan Pemkot Surakarta menunjukan hubungan positif. Artinya, bahwa efektivitas komunikasi Pemkot Surakarta berpengaruh positif terhadap produktivitas pembangunan Pemkot Surakarta, sebaliknya produktivitas pembangunan Pemkot Surakarta berpengaruh positif terhadap efektivitas komunikasi Pemkot Surakarta.

Adapun implikasi teori dari hasil penelitian ini. Pertama, terkait dengan teori komunikasi interpersonal, kedudukan hasil penelitian (fakta) adalah menolak teori yang ada. Dalam penelitian ini untuk mengukur efektivitas komunikasi interpersonal mengacu pendapatnya Cruden dan Sherman (2005). Ada beberapa faktor yang mempengaruhi: completeness (lengkap), conciseness (singkat), consideration (meyakinkan), concreteness (kongkrit), clarity (kejelasan), courtessy (kesopanan), correctness (ketelitian). Dalam konteks ini hasil penelitian (fakta) menolak teori ini. Komunikasi Interpersonal tidak berpengaruh terhadap efektivitas komunikasi Pemkot Surakarta. Artinya, semakin tinggi tingkat komunikasi Interpersonal justru tidak berpengaruh secara signifikan terhadap efektivitas komunikasi Pemkot Surakarta.

Fenomena ini biasa dalam dunia politik bahwa semakin tingginya tingkat popularitas seseorang tidak akan menjamin tingginya tingkat elektabilitas seseorang. Orang terkenal belum tentu didukung. Orang yang retorikanya baik, tidak ada jaminan untuk mendapatkan dukungan. Hal yang sama dalam penelitian ini bahwa tingginya komunikasi interpersonal Pemkot Surakarta akan meningkatkan efektivitas komunikasinya. Justru yang signifikan adalah faktor gaya kepemimpinan demokratis Pemkot Surakarta. Jawaban sederhana bahwa yang dibutuhkan seseorang bukan konsep atau janji, tetapi solusi.

Kedua, terkait dengan teori gaya kepemimpinan demokratis, kedudukan hasil penelitian (fakta) memprasai teori (Nazir, 1999). Hal ini bisa dilihat dari beberapa pernyataan (dalil): Pertama, Selama perang dunia II studi mengenai teori kepemimpinan mengalami perubahan arah yang signifikan dari mempelajari ciri-ciri individu menjadi pola perilaku pemimpin yang disebut dengan leadership styles. Dengan demikian maka fokus beralih dari "siapa pemimpin itu" menjadi "bagaimana seorang pemimpin berperilaku atau menjalankan gaya kepemimpinan" Para sarjana membagi tipe kepemimpinan menjadi delapan (8) : 1) Tipe kharismatik. 2) Tipe paternalistic. 3) Tipe militeristis. 4) Tipe otokratis 5) Tipe Lousser Faire. 6) Tipe Populistis. 7) Tipe Administratif. 8) Tipe demokratis.

Gaya kepemimpinan demokratis (democratic leadership style), menurut Robbins dan Coulter 
(2004) bahwa gaya kepemimpinan demokratis mendeskripsikan pemimpin yang cenderung mengikut-sertakan karyawan dalam pengambilan keputusan, mendelegasikan kekuasaan, mendorong partisipasi karyawan dalam menentukan bagaimana metode kerja dan tujuan yang ingin dicapai, dan memandang umpan balik sebagai suatu kesempatan untuk melatih karyawan. Dalam konteks ini hasil penelitian (fakta) tidak sepenuhnya menyalahkan, tetapi juga tidak sepenuhnya membenarkan. Karena menurut mereka (PKL) justru karena solusi yang diberikan oleh Pemkot Surakarta, sehingga mereka mau dan mendukung program penataa dan pembinaan PKL, baik dalam bentuk modal, tempat yang aman, kepastian usaha dan sebagainya.

Sebagaimana yang disebut di atas bahwa hasil penelitian disamping memperkaya teori gaya kepemimpinan demokratis yang dikembangkan oleh Robbins dan Coulter (2004) adalah memperkuat teori kepemimpinan transformatif yang dikembangkan oleh oleh James MacFregor Gurns yang menerapkannya dalam konteks politik. Gagasan ini selanjutnya disempurnakan serta diperkenalkan ke dalam konteks organisasional oleh Bernard Bass (Berry dan Houston, 1993).

Kepemimpinan transformatif merupakan pendekatan untuk mendobrak. Sejauhmana pemimpin dikatakan sebagai pemimpin transformasional, Bass (1990) dan Koh, dkk. (1995) mengemukakan bahwa hal tersebut dapat diukur dalam hubungan dengan pengaruh pemimpin tersebut berhadapan karyawan. Hasil penelitian menunjukkan bahwa faktor lain yang tidak bisa diabaikan atas keberhasilan program penataan dan pembinaan PKL di Surakarta dalam bentuk relokasi PKL dari Monumen Banjarsari ke Pasar Klitikan Notoharjo adalah kemampuan dalam membangun sinergisitas kepemimpinan antara Wali Kota Joko Widodo dan Wakilnya FX Hadi Rudyatmo (Rudy). Keduanya pun terjadi simbiosis mutualisme. Saling mengisi dan membutuhkan. Sehingga sebagai dasar kuat untuk berbagi tugas, bukan berebut kewenangan, termasuk berbagai pendekatan dan solusi yang ditawarkan oleh Pemkot Surakarta dalam konteks penataan dan pembinaan PKL di Surakarta.

\section{G. Kesimpulan}

Berdasarkan uraian di atas bisa ditarik kesimpulan bahwa keberhasilan proses penataan dan pembinaan PKL di Surakarta dalam penilaian PKL tidak hanya dalam konteks proses, yaitu bagaimana tingkat efektvitas komunikasi Pemkot Surakarta, tetapi juga dalam arti hasilnya atau dampaknya, yaitu terlihat dalam produktivitas pembangunan Pemkot Surakarta dalam konteks pembinaan dan penataan PKL, sekalipun dalam katagori sedang.

Hasil penelitian menunjukkan faktor komunikasi interpersonal dan faktor gaya kepemimpinan demokratis secara bersama-sama berpengaruh secara nyata (signifikan) terhadap efektivitas komunikasi Pemkot Surakarta dalam proses penataan dan pembinaan PKL. Namun jika kedua faktor tersebut dilihat secara sendiri-sendiri bahwa penelitian menunjukkan bahwa faktor gaya kepemimpinan demokratis Pemkot Surakarta memberi kontribusi lebih besar daripada faktor komunikasi interpersonal terhadap efektivitas komunikasi Pemkot Surakarta.

Hasil penelitian menujukkan bahwa efektivitas komunikasi dengan produktivitas Pembangunan Pemkot Surakarta menunjukan hubungan positif. Artinya, bahwa efektivitas komunikasi 
Pemkot Surakarta berpengaruh positif terhadap produktivitas pembangunan Pemkot Surakarta, sebaliknya produktivitas pembangunan Pemkot Surakarta berpengaruh positif terhadap efektivitas komunikasi Pemkot Surakarta.

\section{H. Rekomendasi}

Berdasarkan kesimpulan di atas, ada beberapa rekomendasi dari hasil penelitian:

Rekomendasi untuk kebijakan pemerintah pusat suatu hal yang penting dicatat pelajaran dari Pemkot Surakarta dalam penataan dan pembinaan PKL tidak semata-semata menggunakan pendekatan formalitas dan kelembagaan, tetapi yang jauh lebih penting adalah pendekatan personal dan gaya kepemimpinan solutif. Dengan kata lain bahwa setiap program pemerintah senantiasa mendasarkan aspek yuridis dan prosedural. Namun pengalaman Pemkot Surakarta dalam konteks Penataan dan Pembinaan PKL yang sama penting adalah terkait dengan implementasi, eksekusi, pengawalan dan menawarkan berbagai solusi yang tepat.

Rekomendasi untuk kebijakan Pemerintahan Daerah/ Kota dengan momentum otonomi daerah memberi ruang dan kesempatan bagi Bupati maupun Walikota untuk melakukan berbagai kreasi dan inovasi dalam penyelenggaraan pemerintahan, termasuk problem sosialekonomi. Disamping aspek yuridis dan prosedur, juga yang sama penting adalah penguasaan masalah serta solusi yang ditawarkan.

Rekomendasi untuk kebijakan Pemerintahan Kota Surakarta tidak hanya sebagai dasar evaluasi, tetapi untuk menyempurnakan dalam penataan dan pembinaan PKL ke depan. Ada beberapa persoalan yang hingga sekarang belum terseleseikan secara baik, antara lain:

1. Penataan zona yang tidak proposional. Misalnya, barang-barang berat (baca: barang bekas) masih ditempatkan di lantai atas.

2. Juga terkait dengan setting ruang yang belum ideal, sehingga banyak kios tidak berfungsi sebagai layaknya. Misalnya, hanya sebatas sebagai gudang.

3. Problem parkir, baik dari segi tempat dan tarip yang sering diputuskan sepihak, tanpa melibatkan pedagang.

4. Mengembalikan Paguyuban Pedagang kepada "khithah", yang berorientasi pada kepentingan komunitas, bukan individu-individu.

5. Komitmen Pemkot Surakarta masih dipandang penting untuk keberlanjutan Program Penataan dan Pembinaan PKL di Surakarta.

\section{Bibliografi}

Alisjahbana. (2003). Urban Hidden Economy-Peran Tersembunyi Sektor Informal Perkotaan . Surabaya: Lembaga Penelitian ITS.

Anwari, WMK, (2012), "Penggusuran PKL dan Politik Pemerintahan Kota”, dalam http://www. 
kompas.co.id/kompas-cetak/0312/04/opini. (diakses 16 Juli 2012)

Badri, M., (2008), “Komunikasi Inovasi dalam Perspektif Komunikasi Pembangunan”, Makalah Forum Dosen, 9 September.

Berlo, D.K. (1960). The Process of Communication An Introduction to Theory and Practice. New York: Rinchart and Winston, Inc.

Breman, J. (1991). Sistem Tenaga Kerja Dualistis: Suatu Kritik Terhadap Konsep Sektor Informal, disunting oleh Manning, dalam Urbanisasi, Pengangguran, dan Sektor Informal di Kota. PPSK Universitas Gadjah Mada Kerjasama dengan Yayasan Obor Indonesia. Jakarta.

Bulan, Wahidah R., (2013). Local Reform di Kota Solo Pada Era Kepemimpinan Jokowi (Tahun 2005-2012) - Tindakan Agen Mempengaruhi Struktur dan Relasi Multi Aktor pada Kasus Penataan PKL dan Pemukiman Bantaran Bengawan Solo. Disertasi. Dalam rangka untuk memperoleh gelar Doktor. Program Studi Sosiologi. FISIP, UI.

Cresswell, J. W. (2010). Research Design: Pendekatan Kualitatif, Kuantitatif dan Campuran. Yogjakarta, Pustaka Pelajar, 2010, Cet. I

Devito JA.(1995). The Interpersonal Communication Book, 7th Ed., Hunter College of The City University of New York.

Dewan Riset Nasional dan Bappenas,(1995), Pengembangan Sektor Informasi Pedagang Kaki Lima di Perkotaan, Dewan Riset Nasional dan BappenasBekerjasama dengan Puslitbang Ekonomi dan Pembangunan Lembaga Ilmu Pengetahuan Indonesia.

Dilla, S. (2007). Komunikasi Pembangunan: Pendekatan Terpadu. Simbiosa. Bandung.

Gonzalez, Hernando. (1993). Beberapa Mitos Komunikasi dan Pembangunan. Terdapat dalam Jahi, Amri (Penyunting). Komunikasi Massa dan Pembangunan Pedesaan di Negaranegara Dunia Ketiga: Suatu Pengantar. Jakarta: Gramedia Pustaka Utama.

Goran, H. (1986). Communication and Social Change in Developing Nations: A Critical View. The Iowa State University Press/Ames.

Handayani, S. (2008), “Memahami Pelaku Sektor Informal Perkotaan: Penataan Pedagang Kaki Lima Tanpa Kekerasan", Jurnal AKATIGA Bandung, Oktober.

Hart, K. (1991). Sektor Informal dan Struktur Pekerjaan di Kota. disunting oleh Manning, dalam Urbanisasi, Pengangguran,dan Sektor Informal di Kota. PPSK Universitas Gadjah Mada Kerjasama dengan Yayasan Obor Indonesia. Jakarta. 
Laporan Sosial Indonesia (1998). Kemiskinan, Pengangguran dan Setengah Pengangguran. BPS. Jakarta.

Malik, Dedy Djamaluddin, (1991). Komunikasi Pembangunan: Bandung, Perspek-Depedensia. Manning, Chris dan Tadjuddin Noer Effendi, (1996), Urbanisasi,Pengangguran, dan Sektor Informal di Kota. Yayasan Obor Indonesia, Jakarta.

McGee, T. G., (1971), The Urbanization Process in The Third World: Exploration in Search of a Theory. London: G. Bell \& Sons.

McQuail, Denis. 2000. Mass Communication Theory. Fourth ed. London: Sage Publications Inc. Moleong, Lexy J. (2011). MetodePenelitian KualitatifEdisi Revisi. Bandung: Remaja Rosdakarya. Muhadjir, N., (2000), Metodologi Penelitian Kualitatif, Yogjakarta: Rake Sarasin.

Mulyana, D., (2000). Ilmu Komunikasi-Suatu Pengantar.PT. Remaja Rosdakarya, Bandung.

Musharyo, B., (2008), "Kebijakan Fleksibilisasi Pasar Kerja dan Proses Informalisasi Ketenagakerjaan”, dalam Jurnal Forum Pendamping Buruh Nasional (FPBN) edisi 8, Sept - Maret.

Nazir, M., (1999), Metode Penelitian, Jakarta : Ghalia Indonesia, Cet. IV.

Peraturan Daerah Kotamadya Daerah Tingkat II Surakarta Nomor 8 Tahun 1995 tentang Penataan dan Pembinaan Pedagang Kaki Lima (PKL).

Perda Kota Surakarta No. 7 Tahun 2009 Tentang Retribusi Pemakaian Kekayaan Daerah;

Perda No. 3 Tahun 2008 Tentang Pengelolaan PKL Kota Surakarta.

Priyono, Amy (1996). Sektor Informal,Ulet dan Lentur, dalam Forum Ekonomi, Tahun V.No.36.

Pye, Lucien E. (Editor) (1963). Communications and Political Development. Princeton: Princeton University Press.

Rachbini, Didik, J dan Abdul Hamid,(1994), Ekonomi Informal Perkotaan Gejala Involusi Gelombang Kedua, LP3ES, Jakarta.

Robert K. Yin. (2002). Case Study Research. Design and Methods. Edisi ketiga. Applied social research method series Volume 5. Sage Publications. California. ISBN 0-7619-2553-8.

Rogers, E.M. (1989). Perspektif Baru dalam Komunikasi Pembangunan: Suatu Tinjauan. In: EM Rogers, ed. Komunikasi dan Pembangunan: M Perspektif Kritis. Terjemahan dari Communication and Development. LP3ES. Jakarta 
Rogers, E.M., (2003). Diffusion of Innovations: Fifth Edition. Free Press. New York.

Roucek, J.S., and Warren, R.S. (1963). Sociology An Introduction. New Jersey: Littlefield, Adams \& Co, Paterson.

Sajogyo, ed. (1997). Menciptakan Visi: Mendukung Pengembangan Kelompok Swadaya Mandiri dalam Gerakan Nasional PPK. Puspa Swara. Jakarta

Sarjono, Y. (2006). Pergulatan Pedagang Kaki Lima di Perkotaan - Pendekatan Kualitatif. Surakarta: Muhammadiyah University Press.

Schramm, W.(1964). Peranandan Bantuan Mass Mediadalam PembangunanNasional. Terjemahan: Mass Media and National Development. In: E Depari, C MacAndrews, eds. 1991. Peranan Komunikasi Massa dalam Pembangunan: Suatu Kumpulan Karangan. Gadjah Mada Univ. Pr. Yogyakarta

Sethuraman,"Sektor Informal di Negara Sedang Berkembang", dalam Chris Manning dan Tadjudin Noer Effendi,(1985),"Urbanisasi, Pengangguran, dan Sektor Informal di Kota, Jakarta: PT Gramedia.

SK Walikota Surakarta No. 2 Tahun 2001 tentang Pedoman Pelaksanaan Perda No. 8 Tahun 1995 ;

Struktur Organisasi dan Tata Kerja (SOTK) Kota Surakarta No. 6 Tahun 2008 Tentang Struktur Organisasi dan Tata Kerja Dinas Pengelolaan Pasar Kota Surakarta.

Sudiro. (2006). Pedagang Kaki Lima (PKL) ota Wonosari dan pelaksanaan Perda Kabupaten Gunungkidul Nomor 12 Tahun 2003. Dalam rangka menempuh gelar Magister Sosiologi (Kebijakan dan Kesejahteraan Sosial) UGM.

Sugiyono. (2007). Metode Penelitian Kuantitatif-Kualitatif dan $R \& D$. Bandung: Alfa Beta.

Supriatna, T. (2000), Strategi Pembangunan dan Kemiskinan. Jakarta: Rineka Cipta.

Tim Penyusun. (2006). Kajian Hukum Tentang Pedagang Kaki Lima (PKL) di Kota Surakarta. Surakarta: Bagian Hukum dan HAM Sekretariat Daerah, Pemkot Surakarta, Tahun Anggaran 2006.

Tim Survei dan Pemetaan. (2007). Pedagang Kaki Lima di Kota Surakarta. Surakarta: Kantor PengelolaanPedagang Kaki Lima - Pemkot Surakarta, Tahun Anggaran 2007.

Todaro, Michael P. (2000), Pembangunan Ekonomi di Dunia Ketiga Edisi Ketujuh, terjemahan, Tiara Wacana, Yogyakarta.

Undang-undang No. 32 Tahun 2004 Tentang Pemerintahan Daerah. 